Quṣayr'Amra 
I. Art and Ceremony in Late Antiquity, by Sabine G. MacCormack

II. Synesius of Cyrene: Philosopher-Bishop, by Jay Alan Bregman

III. Theodosian Empresses: Women and Imperial Dominion in Late Antiquity, by Kenneth G. Holum

IV. John Chrysostom and the Jews: Rhetoric and Reality in the Late Fourth Century, by Robert L. Wilken

V. Biography in Late Antiquity: The Quest for the Holy Man, by Patricia Cox

VI. Pachomius: The Making of a Community in Fourth-Century Egypt, by Philip Rousseau

VII. Change in Byzantine Culture in the Eleventh and Twelfth Centuries, by A. P. Kazhdan and Ann Wharton Epstein

VIII. Leadership and Community in Late Antique Gaul, by Raymond Van Dam

IX. Homer the Theologian: Neoplatonist Allegorical Reading and the Growth of the Epic Tradition, by Robert Lamberton

X. Procopius and the Sixth Century, by Averil Cameron

XI. Guardians of Language: The Grammarian and Society in Late Antiquity, by Robert A. Kaster

XII. Civic Coins and Civic Politics in the Roman East, A.D. 180-275, by Kenneth Harl

XIII. Holy Women of the Syrian Orient, introduced and translated by Sebastian P. Brock and Susan Ashbrook Harvey

XIV. Gregory the Great: Perfection in Imperfection, by Carole Straw

XV. "Apex Omnium": Religion in the "Res gestae" of Ammianus, by R. L. Rike

XVI. Dioscorus of Aphrodito: His Work and His World, by Leslie S. B. MacCoull

XVII. On Roman Time: The Codex-Calendar of 354 and the Rhythms of Urban Life in Late Antiquity, by Michele Renee Salzman

XVIII. Asceticism and Society in Crisis: John of Ephesus and The Lives of the Eastern Saints, by Susan Ashbrook Harvey

XIX. Barbarians and Politics at the Court of Arcadius, by Alan Cameron and Jacqueline Long, with a contribution by Lee Sherry 
XX. Basil of Caesarea, by Philip Rousseau

XXI. In Praise of Later Roman Emperors: The "Panegyrici Latini," introduction, translation, and historical commentary by C. E. V. Nixon and Barbara Saylor Rodgers

XXII. Ambrose of Milan: Church and Court in a Christian Capital, by Neil B. McLynn

XXIII. Public Disputation, Power, and Social Order in Late Antiquity, by Richard Lim

XXIV. The Making of a Heretic: Gender, Authority, and the Priscillianist Controversy, by Virginia Burrus

XXV. Symeon the Holy Fool: Leontius's Life and the Late Antique City, by Derek Krueger

XXVI. The Shadows of Poetry: Vergil in the Mind of Augustine, by Sabine MacCormack

XXVII. Paulinus of Nola: Life, Letters, and Poems, by Dennis E. Trout

XXVIII. The Barbarian Plain: Saint Sergius between Rome and Iran, by Elizabeth Key Fowden

XXIX. The Private Orations of Themistius, translated, annotated, and introduced by Robert J. Penella

XXX. The Memory of the Eyes: Pilgrims to Living Saints in Christian Late Antiquity, by Georgia Frank

XXXI. Greek Biography and Panegyric in Late Antiquity, edited by Tomas Hägg and Philip Rousseau

XXXII. Subtle Bodies: Representing Angels in Byzantium, by Glenn Peers

XXXIII. Wandering, Begging Monks: Social Order and the Promotion of Monasticism in the Roman East, 360-451 C.E., by Daniel Caner

XXXIV. Failure of Empire: Valens and the Roman State in the Fourth Century A.D., by Noel Lenski

XXXV. Merovingian Mortuary Archaeology and the Making of the Early Middle Ages, by Bonnie Effros

XXXVI. Qusayr 'Amra: Art and the Umayyad Elite in Late Antique Syria, by Garth Fowden 
This page intentionally left blank 


\section{Qușayr 'Amra}

Art and the Umayyad Elite in Late Antique Syria

\section{GARTH FOWDEN}

Centre for Greek and Roman Antiquity

National Research Foundation, Athens

University of California Press

BERKELEY LOS ANGELES LONDON 
University of California Press

Berkeley and Los Angeles, California

University of California Press, Ltd.

London, England

C 2004 by the Regents of the University of California

Library of Congress Cataloging-in-Publication Data

Fowden, Garth.

Qușayr 'Amra : art and the Umayyad elite in late antique Syria / Garth Fowden.

p. $\quad \mathrm{cm}$. - (The transformation of the classical heritage ; 36 )

Includes bibliographical references (p. ) and index.

ISBN 0-520-23665-3 (cloth : alk. paper).

I. Mural painting and decoration, Umayyad-Jordan-Foreign

influences. 2. Quṣayr 'Amrah (Jordan : Dwelling) 3. Arabic poetry-622-750-History and criticism. I. Title: Art and the Umayyad elite in late antique Syria II. Title. III. Series.

$$
\begin{aligned}
& \text { ND2819.J6F69 } 2004 \\
& \text { 751.7'0956959-dc21 }
\end{aligned}
$$

Manufactured in the United States of America

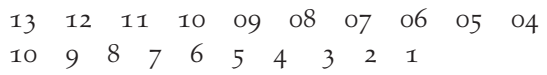

The paper used in this publication is both acid-free and totally chlorinefree (TCF). It meets the minimum requirements of ANSI/NISO Z39.48-1992 (R 1997) (Permanence of Paper).@ 
For my father and mother who introduced me to Syria

(Beirut and Jerusalem, Easter 1966) and for Iason

who allowed himself to be introduced (Aleppo and Beirut, Easter 1996) 
This page intentionally left blank 